\title{
3 Social Enterprise in the Czech Republic
}

\author{
Heritage and New \\ Developments
}

\author{
Marie Dohnalová, Durmish Guri, \\ Jaroslava Hrabětová, Kateřina Legnerová \\ and Vènceslava Šlechtová
}

\section{Introduction}

The term "social enterprise" (SE) is used in the Czech Republic; however, it has not yet been legally acknowledged. It is particularly used by social enterprises with different legal forms, by non-governmental organisations that promote the idea of social entrepreneurship and support social enterprises as well as by individuals who consider starting up a social enterprise.

Some facts create suitable conditions for the establishment and development of social enterprises in the country, and research confirms the actual existence of social enterprises, even though a formal definition of the concept is still lacking. Foreign concepts and experiences, especially from the European Union countries, serve as the basis for developments in the Czech Republic-which was, it is worth noting, the first country in Central and Eastern Europe to hold an international conference on the social economy, in 2002. One of the outputs of this conference was the "Declaration of Prague", which highlights three major features of social enterprise: social enterprise is not based on capital but on participatory democracy; the object is not the pursuit of profit but mutual support; and social enterprise can make a significant contribution to the inclusion of disadvantaged people into society.

Knowledge of foreign theory and practice about the social economy helps to spread ideas about social enterprise in the country and supports the establishment of Czech social enterprises (Dohnalová 2010). A nonofficial group of experts and interested people was recently established with the aim of defining the social economy and social enterprise nowadays. The term "social enterprise" is also used by academics, particularly at the Faculty of Humanities of Charles University in Prague. A course on "Social economy and social entrepreneurship", accredited by the Ministry of Education of the Czech Republic as an obligatory course in 
the master study programme "Civil-Sector Studies", is organised by the Department of Civil-Society Studies within this Faculty.

\section{Understanding Context and Concepts}

\subsection{Historical and Legal Background for SE Development}

The background for SE development in the Czech Republic is a long and rich tradition of solidarity, mutual-help organisations, foundations and cooperatives; such organisations have indeed existed under different forms in the country for over 100 years. Efforts to establish associations and cooperatives, which seem to constitute the "roots" of Czech social enterprises, are documented in the country at the beginning of the 19th century already. Well-known figures who formulated basic principles of economic individualism and solidarity were František Cyril Kampelík (1805-1872), František Ladislav Chleborad (1839-1911) and Karel Engliš (1880-1961). The First Republic of Czechoslovakia, under the presidency of Tomáš Garrigue Masaryk (1850-1937), created a friendly environment for the development of civil organisations. The high number of associations between World War I and World War II was linked to the civil activities started in the 18th and 19th centuries and related to the Czech National Revival. The New Liberal Federal Law, passed in 1867 (Act No. 134/1867), enabled the establishment of different types of associations; this law remained in force until 1951. In that period, Czechoslovakia was one of the world's ten most industrialised countries. Associations and public organisations' growth was mainly related to the development of Czech small and medium enterprises in the second half of the 19th century; the new social class of Czech wealthy businessmen played an important role in philanthropy. Most of them became famous patrons. The well-known architect Josef Hlávka, for example, established the "Nadání Josefa, Marie a Zdeňky Hlávkových" Foundation, which still operates nowadays (Skovajsa 2010). Another well-known patron was Alois Oliva, who established Oliva's Foundation in 1896.

The Act of 1873 (Act No. 70/1873 about Profitable and Productive Cooperatives) defined cooperatives as organisations based on mutual support among the members. The eldest production cooperative in the country, "Kovo Věšín”, was founded in 1892. Many cooperatives were developed in every business sector at the end of the 19th century, and the period between World War I and World War II is considered as the "golden years" of Czech cooperatives.

Plenty of charitable organisations were founded after World War I with the aim of alleviating the consequences of the war. The number of active public and humanitarian organisations increased significantly between 1919 and 1931 and reached its maximum in 1938, with 9,115 public 
associations registered (Rataj and Ratajová 1998). But based on government regulation, from 1939 onwards, all associations were immediately or gradually dissolved.

All associations, foundations and cooperatives quickly resumed their activities after World War II, but February 1948 brought about significant changes. Indeed, public associations were prohibited by the new social regime, and only Hlávka's foundation (the "Nadání Josefa, Marie a Zdeňky Hlávkových" Foundation) remained. Productive cooperatives also remained, although under a different shape-as a tool of the communist regime. The economy was characterised by comprehensive central planning and the abolition of private ownership of capital.

The 1970s brought about a more authoritarian socialism, in which all public life was under control and no public organisations were allowed to operate. This situation persisted until the end of communism, in November 1989.

The "Velvet Revolution" brought about civil liberty and the collapse of the Communist Party. This regime changeover triggered the renewal of many public associations. A wide range of new associations and cooperatives of a social type were founded (see Section 3). The development of the civil sector after 1989 constituted the basis for the emergence of today's social enterprises.

\subsection{Social Enterprise Nowadays}

Social enterprises in the Czech Republic emerge from a "bottom-up" approach; they are based on citizens' voluntary initiatives. New jobs are usually created and people from disadvantaged social groups are employed. Social enterprises offer products and services in towns and municipalities. As already mentioned earlier, the first international conference on the social economy to be organised in post-communist countries took place in Prague in 2002; although it did not bring about any incentives for social enterprises, it was nevertheless important for Czech social enterprises.

The real beginnings of the SE phenomenon in the Czech Republic are mainly connected with the implementation of projects supported by the European Structural Funds. From 2003 to 2008, non-governmental organisations (cooperatives and registered companies) often established international cooperation relations, gained experience from abroad and started to call themselves "social enterprises" or "social companies". The interest to establish social enterprises was supported by the Human Resources and Employment Operational Programme of the European Social Fund. Between 2009 and 2013, the Ministry of Labour and Social Affairs defined, in its call for grant-applying projects in the social economy, the requirements to be fulfilled for an organisation to be considered as a social enterprise. 
The concept of social enterprise is mainly connected in the Czech Republic with the employment of disabled people. The legislative background supports these social enterprises by providing subsidies for the creation of jobs complying with the code of employment. However, thanks to the call issued by the European Social Fund, the concept of social enterprises has become broader and now includes the employment of people belonging to other groups that are considered as socially disadvantaged: the youth and young adults (people between 15 and 26 endangered by social pathological phenomena, and young adults leaving institutional care); homeless people; people leaving institutional or protective care and people leaving prison; victims of crime, of domestic violence, of human trafficking, and commercially exploited people; people caring for a relative; people with experience of drug addiction and people with diagnosed addiction to drugs; and other unspecified socially excluded people or people at risk of social exclusion.

Two main reasons can account for the emergence and strength of the topic of social enterprise. First, as mentioned earlier, social enterprises are created through a "bottom-up" approach; the activity is carried out by the subjects themselves. People initiating social enterprises have often gained experience with social enterprises from abroad, so they refer to their initiatives as "social enterprises". The second reason is connected with financial support from the European Social Fund, which was allocated, within the "Social Economy" call, to projects dealing with newly established social enterprises. This factor has proven very important for the current programming period (2014-2020), as social enterprises have been supported by different operational programmes of the European Social Fund concerning the fight against poverty, employment support, social inclusion and support to small and middle-sized enterprises.

Social enterprises' weaknesses in the Czech Republic can be related to the following obstacles, which were highlighted by Borzaga et al. (2008) in their analysis of the situation in post-communist countries:

- government policies relying on the strength of the free market and underestimating the value of alternative organisations and enterprises, particularly regarding regional development;

- deficiencies of the legislative framework that should regulate the profit-generating activities of the third sector;

- problems encountered by social enterprises in mobilising human and financial resources (lack of resources, lack or insufficiency of experience with entrepreneurship and marketing and lack of knowledge about how to work with disadvantaged social groups);

- distrust in cooperatives caused by a negative understanding of cooperatives as organisations connected with the communist regime (even though there are cooperatives that were established before the communist era); 
- high dependence of social-sector NGOs on the state;

- insufficient recognition of the role of the third sector as an alternative sector;

- influence of financing opportunities on the activities of NGOs (even though non-governmental organisations are established for the purpose of fulfilling a social mission, they sometimes adjust their activities to the possibilities of financial support);

- general lack of trust in solidarity (the concept of solidarity is understood as applying to the relationship of an individual with friends and family; the vision of economic activity is connected with individual targets rather than with possible positive effects for the entire society);

- continuing influence of the political culture of the previous regime, in which the activity of social-economy actors was limited to their members' own interests.

Beyond these various obstacles, the biggest problem remains the lack of knowledge of the concepts of social enterprise, social entrepreneurship and social economy in the general public. Indeed, why should an enterprise be established as a social enterprise when this does not work as a "positive sign" to distinguish the enterprise from other enterprises, when the public does not hold social enterprise in high regard, and when most of the people do not even know what a social enterprise is?

\subsection{Social Enterprise or Civil Sector?}

The term "social enterprise" is still not well-known in the Czech Republic, but there are other terms that are used in connection with (or instead of, or besides) that of social enterprise.

The "civil sector" and the "non-profit sector" are the concepts most frequently used in the country. The civil sector and non-profit sector are usually defined by listing the types of (not-for-profit) organisations that compose it: associations, foundations, endowment funds, church institutions and charitable trusts. These are private organisations, distinct from the state and involved in economic activities. They are characterised by the fact that their activities are not only oriented by the search for profit; they also fulfil other missions and pursue other visions. People who set them up voluntarily establish organisations with social-welfare targets. These organisations provide public services; they work for their members, for foundations supporting the activity of others, etc. They can be local or national, and they often arise in reaction to concrete problems and needs. They are present in nearly all fields of human activity and their financing comes from various sources.

The concept of "social economy" is not well-known either in the Czech Republic. The notion of social economy is little used, and the awareness 
about the concrete meaning of the term is really low. The social economy and organised civil society represent in many ways the same realities, and these terms are often used interchangeably. Generally speaking, the social economy overlaps with the civil sector to a great extent; however, it is not exactly the same. Indeed, the social economy is a larger concept than the civil sector, to the extent that it includes market-oriented organisations (cooperatives, some trading companies); on the other hand, it is also a narrower concept, to the extent that civil-sector organisations which do not carry out any economic activity are not included in the social economy.

\subsection{Existing Research in the Field of Social Enterprise}

Although the term "social enterprise" is not yet legally acknowledged in the Czech Republic, there is some existing research on the subject, and some authors have already worked on social enterprise.

The main institution that focuses part of its work and research on social enterprise is the Faculty of Humanities at Charles University in Prague. Social economy and social enterprise constitute one of the main research topics of this Faculty's Department of Civil-Society Studies, in connection with foreign institutions since 2002.

Two other institutions also focus part of their work and research on social enterprise: the Research Institute for Labour and Social Affairs and the charitable trust P3-People, Planet, Profit. Since 2011, this trust has spread the idea of social economy and social enterprise in Czech society. The trust provides consultancy in the field of social enterprise, it supports the preparation of projects for establishing social enterprises and implements projects to support and promote social enterprises. In 2009, the trust created the "TESSEA Thematic Network for the Development of the Social Economy" (TESSEA Tematická sit pro sociální ekonomiku); since then, the trust has coordinated this network's activity.

\subsection{Public Authorities' Interest for Social Enterprise}

Among public institutions, the entity that has demonstrated most interest for the concept of social enterprise is the Ministry of Labour and Social Affairs. In 2010, this Ministry defined the concept of social enterprise in the framework of the "Social Economy (2009-2013)" grant scheme. Social enterprises applying for grants under the calls for proposals launched by this global scheme had to fulfil several criteria:

- The enterprise must contribute to the reduction of unemployment and it must support social inclusion (at least $30 \%$ of all the social enterprise's employees must belong to specific target groups).

- Employees should participate in the decision-making process. 
- The enterprise's profit has to be used for the development of the enterprise and/or to fulfil a mission of public benefit (at least $51 \%$ of the profit should be reinvested into the social enterprise).

- The enterprise should be locally oriented, use local resources, support local needs and contribute to local development.

Two government advisory bodies also use the term "social enterprise": the Government Council for Non-Governmental Non-Profit Organisations (Rada pro nestátní neziskové organizace) looks for possibilities for non-governmental non-profit organisations to gain their own income, while the Agency for Social Inclusion (Agentura pro sociální začleňováni) focuses on the employment of disadvantaged people as a social-inclusion tool, particularly in socially deprived areas.

Social enterprises bear economic risk, try to find innovative ways to provide services and generate income, meet public and social needs and contribute to local development. As in other European countries, social enterprises in the Czech Republic generate new jobs, employ people from disadvantaged groups and provide social services. Undoubtedly, social enterprises are going to develop in many areas of the country's life in the years to come.

\section{Definition of Social Enterprise}

As already mentioned, a specific legislative framework for social entrepreneurship and the social economy is still lacking in the Czech Republic. The country's current legal system does not recognise the concepts of social economy and social entrepreneurship.

In the Czech Republic, companies operating under commercial law can follow the principles of social entrepreneurship (e.g. reinvestment rules). The lack of a legislative framework for social entrepreneurship and social economy in the country might appear not to be an obstacle to their development, but it is indeed, and it would thus be necessary to lay down rules, anchored in the Czech legal order, to regulate the field. We believe that it would be important, for social entrepreneurship and the social economy, that a legal framework be established and subsequently adapted if necessary so as to reflect changes in the development of the social economy in the country, as has happened abroad.

Researchers in the Czech Republic use two current foreign approaches to define the social economy and social enterprises: the legal/institutional approach and the normative approach. ${ }^{1}$ Five factors are important to understand the current status and development of social enterprise:

- The influence of foreign definitions: international definitions, and in particular the EMES approach, have exerted and still exert a 
significant influence on the definition of the concept and indicators of social enterprise in the Czech context.

- "Bottom-up" initiatives from the civil sector: these initiatives, whose origins are to be found in civil-society organisations (NPOs), create a model of social enterprise referred to as the "associative model". Social entrepreneurship is expected to complement the organisations' financial resources by increasing the importance of the income they generate.

- "Bottom-up" initiatives from the cooperative sector: these initiatives, whose origins are to be found in cooperatives, create a model of social enterprise called the "cooperative model". These initiatives are part of a cooperative tradition that dates back to the 19th century and to the so-called "disabled workers cooperatives" from the socialist era.

- "Bottom-up" initiatives from the commercial sector: these initiatives are business companies and self-employed persons (limited-liability companies, stock corporations, public companies and special partnerships). They adopt business models but with the addition of a social objective and are thus referred to as the "business model" of social enterprise.

- The impact of the European environment: funding from European funds and operational programmes to promote the social economy and social entrepreneurship led to the creation of work-integration social enterprises-the so-called "WISE model". WISEs create jobs and employ people from disadvantaged social groups (both in the civil, cooperative and in the business sectors).

The EMES International Research Network proposes a set of indicators, based on an empirical approach, to define an ideal-type of social enterprise. In the absence of a specific legislative framework for social enterprise, and in a context characterised by the "bottom-up" emergence of initiatives, the EMES approach constitutes the basis for current research on Czech social enterprise.

Like in other countries, social enterprises in the Czech Republic perform economic activities qua private entities. They differ from profitable companies to the extent that they pursue social and/or environmental goals. They often employ people from disadvantaged social groups and contribute to social inclusion and to the fight against unemployment.

From 2008 to 2010, the research team of the Department of Civil-Society Studies (Faculty of Humanities, Charles University) carried out research on the Czech social economy using an international definition of the social economy which combines a legal/institutional approach and a normative approach (Defourny et al. 1999; Noya and Clarence 2007). ${ }^{2}$ According to the international legal/institutional approach, the social economy is made 
up of different legal entities, namely non-profit organisations, cooperatives, mutual societies and foundations. The normative approach highlights values and principles guiding these entities' actual behaviours.

On this basis, the researchers from the Faculty of Humanities of Charles University came to the conclusion that the Czech social economy is made up of the following entities, independent from the state:

- public-benefit organisations;

- associations;

- legal persons established by the church and religious societies and performing an economic activity to finance their mission or to support the employment of hard-to-employ groups of people in the labour market;

- cooperatives (especially manufacturing cooperatives);

- business companies established for purposes other than business;

- self-employed people from socially disadvantaged groups.

The research carried out between 2008 and 2010 focused on publicbenefit organisations in the social field. Public-benefit organisations are legal persons that can develop economic activities-with one restriction: they cannot hold shares in other business entities.

TESSEA, an opinion platform supporting social enterprises and the social economy, was created in 2009. This platform was established within the project "Thematic Network for the Development of the Social Economy", which was co-financed by the European Social Fund and the Czech government. The public-benefit organisation Nova ekonomika was the initiator of the working group "Definition" within TESSEA; it used the indicators of social enterprise developed by the EMES Network. The group worked out a definition and a table of principles of social enterprise (see Table 3.1) adapted to the Czech environment (Dohnalová et al.2011).

Social enterprise is defined as a "subject of social entrepreneurship"; it is a legal person founded according to private law or a part of a legal person or a natural person that complies with the principles of social enterprise. The social enterprise pursues a goal of public benefit, which is formulated in its founding documents. It is established and developed on the basis of the socalled "triple bottom line" (economic, social and environmental) concept.

\section{Identification of SE Models}

Four main models of social enterprise can be identified in the Czech Republic:

- the associative model, which consists of civil-sector organisations or different types of non-profit organisations (associations, 
Table 3.1 Principles of social enterprise: the TESSEA framework

\begin{tabular}{|c|c|c|c|}
\hline & Social benefit & Economic benefit & $\begin{array}{l}\text { Environmental } \\
\text { and local benefit }\end{array}$ \\
\hline $\begin{array}{l}\text { Characteristics/ } \\
\text { features, in } \\
\text { accordance } \\
\text { with the } \\
\text { European } \\
\text { understanding } \\
\text { of social } \\
\text { enterprise } \\
\text { Social } \\
\text { enterprises } \\
\text { have to } \\
\text { fulfil-or } \\
\text { to evolve } \\
\text { towards the } \\
\text { fulfilment of- } \\
\text { these criteria. } \\
\text { Characteristics } \\
\text { in italics } \\
\text { are not } \\
\text { compulsory. }\end{array}$ & $\begin{array}{l}\text { (a) The activity } \\
\text { must benefit } \\
\text { society at large } \\
\text { or specific } \\
\text { groups of } \\
\text { (disadvantaged) } \\
\text { people. } \\
\text { (b) Employees and } \\
\text { members must } \\
\text { take part in } \\
\text { the enterprise's } \\
\text { strategic } \\
\text { planning. } \\
\text { (c) Any possible } \\
\text { profit must be } \\
\text { used primarily } \\
\text { for the } \\
\text { development } \\
\text { of the social } \\
\text { enterprise and/ } \\
\text { or for fulfilling } \\
\text { community } \\
\text { goals. }\end{array}$ & $\begin{array}{l}\text { (a) The enterprise } \\
\text { must perform } \\
\text { a systematic } \\
\text { economic } \\
\text { activity. } \\
\text { (b) The enterprise } \\
\text { must be } \\
\text { autonomous in } \\
\text { its management } \\
\text { decisions; } \\
\text { management } \\
\text { must not be } \\
\text { dependent } \\
\text { on external } \\
\text { founders. } \\
\text { (c) At least a } \\
\text { minimal } \\
\text { share of the } \\
\text { total output } \\
\text { (products or } \\
\text { services) must } \\
\text { be sold on the } \\
\text { market. } \\
\text { (d) The enterprise } \\
\text { must } \\
\text { demonstrate an } \\
\text { ability to cope } \\
\text { with economic } \\
\text { risk. } \\
\text { (e) The enterprise } \\
\text { must use a } \\
\text { combination of } \\
\text { volunteer work } \\
\text { and paid work. }\end{array}$ & $\begin{array}{l}\text { (a) Priority must } \\
\text { be given to } \\
\text { satisfying } \\
\text { the needs } \\
\text { of the local } \\
\text { community. } \\
\text { (b) The enterprise } \\
\text { must favour } \\
\text { and use local } \\
\text { resources. } \\
\text { (c) The enterprise } \\
\text { should } \\
\text { preferably } \\
\text { satisfy the } \\
\text { local demand. } \\
\text { (d) The enterprise } \\
\text { must respect } \\
\text { environmental } \\
\text { aspects in } \\
\text { production } \\
\text { and } \\
\text { consumption. } \\
\text { (e) The enterprise } \\
\text { must cooperate } \\
\text { with important } \\
\text { local players. } \\
\text { (f) The enterprise } \\
\text { should } \\
\text { implement } \\
\text { an innovative } \\
\text { approach and } \\
\text { innovative } \\
\text { solutions. }\end{array}$ \\
\hline
\end{tabular}

public-benefit organisations, institutes, foundations and registered church legal entities);

- the cooperative model;

- the business model, which includes business companies and selfemployed persons (limited-liability companies, stock corporations, public companies and special partnerships); and

- the WISE model, which is the most frequently encountered type of social enterprise in the Czech Republic. 


\subsection{Civil-Sector SE Model}

Civil-sector entities were affected by changes that occurred in the Czech Republic in connection with the new Civil Code, which came into force on January 1,2014 . These changes concerned not only the names of the organisations concerned but also their ability to exercise an economic activity.

Using the "structural-operational" definition mentioned earlier, civilsector social enterprises are defined as:

- organisations, that is, they have an institutional structure and existence. They are usually legal persons;

- private, that is, they are institutionally separate from the government, although they may receive public funding and may have public officials on their governing bodies;

- self-governing, that is, they are able to control their own activities and free to select and dismiss their governing bodies;

- non-profit-distributing, that is, not-for-profit organisations may make profits but these must be ploughed back into the organisation's main mission and not distributed to the owners, members, founders or governing bodies of the organisation;

- voluntary, which means two things: firstly, that membership is not compulsory or legally imposed; and secondly, that these organisations must have volunteers participating in their activities or management.

In the Czech context, the following organisations fulfil the earlier conditions:

- associations;

- public-benefit organisations;

- institutes;

- foundations;

- legal persons established by the church and religious societies.

\subsection{Cooperative-Sector SE Model}

A cooperative is a non-restricted community of people, which is established to support each of its members or third parties, or for business purposes.

A "social cooperative" ( $\$ 758-773$ of Act No. 90/2012 Collection on Corporations) is a specific type of cooperative that consistently develops charitable activities aimed at promoting social cohesion for the vocational and social integration of disadvantaged persons. Its primary goal is to satisfy local needs, using local resources, according to the place of location and scope of the organisation. Social cooperatives are active especially in the area of job creation, social services and health care, education, housing and sustainable development. According to the Business 
Corporations Act, social cooperatives are not entitled to any specific advantage or benefit.

Disabled workers' cooperatives employ persons with a handicap, so with a reduced working ability. Jobs for these people are managed through the labour offices.

Unlike all legal entities arising under the Civil Code (associations, foundations, endowment funds and institutes), cooperatives are in practice unable to perform secondary economic activities: a cooperative can only perform the activity for which it was founded.

\subsection{Business-Sector SE Model}

Commercial companies are legal entities that are established for business purposes, that is, they systematically work towards making profit. However, the Czech law also allows to establish the same type of companies but with non-profit activities. The legal forms under which such enterprises can operate are:

- the limited-liability company;

- the public company.

\subsection{Work-Integration SE Model}

The work-integration social enterprise (WISE) is currently the only form of social enterprise that is officially defined and recognised in the Czech Republic. In its call for grant-applying projects within the "Social Economy" part of the Human Resources and Employment Operational Programme, the Ministry of Labour and Social Affairs of the Czech Republic formulated the requirements that an enterprise has to meet to be recognised as a social enterprise.

Work-integration social enterprises are autonomous economic entities whose main objective is the work integration of unemployed people (whether within the social enterprise itself, or within enterprises in the open labour market) who have difficulties to succeed in the job market and who are at risk of long-term exclusion from the labour market. The integration of these individuals back into society is achieved through a productive activity or through retraining the workers.

\section{Institutional Context Shaping the Development of Czech Social Enterprises}

The objective of this fourth section is to identify and describe the main "institutions" (at large) shaping the profile of social enterprises in the Czech context: the legal framework within which social enterprises operate and major platforms for social enterprises. 


\subsection{Legal Framework}

As already mentioned in the previous sections, social enterprise, social entrepreneurship and the social economy have not yet been defined by Czech law ${ }^{3}$ (Dohnalová 2012). Various experts are currently working on the preparation of a specific law on social entrepreneurship, but it is not certain when this law will be passed.

The only law specifically related to social enterprise is Act No. 435/2004 Collection on Employment; it concerns primarily WISEs. Another law, namely Act No. 262/2006 Collection of the Labour Code, is also important for social enterprises-as it is for all enterprises.

\section{Act No. 435/2004 Collection on Employment}

This law defines the relations between employers and employees in the Czech Republic and regulates the relationship between the state and employers of people with disabilities. People with disabilities receive a higher degree of protection in the labour market. The state provides financial contributions only to social enterprises that employ persons with disabilities; the consequence of this is that most of the social enterprises do. These financial contributions are an important financial source, which is regular and helps with cash flow. However, in the current context of reduction of state expenses, the state reduces the volume of funds available for these enterprises, which has a significant impact on them.

\section{Act No. 262/2006 Collection of the Labour Code}

The Labour Code regulates the general rules relating to employment relationship, labour agreements, working hours and rest periods, safety and health protection, remuneration rules, income deductions, reimbursement of expenses to employees in connection with their work performance, obstacles to work, leave (with pay), care of employees, compensations for damages, employee information and consultation procedure, competence of trade union organisations, work council and representatives for occupational safety and health protection. Social enterprises that employ people must follow the Labour Code.

\subsection{Platforms for Social Enterprises}

The "Association for Social Responsibility" (Asociace společenské odpovédnosti, or A-CSR) is an open and independent platform that unites, connects and represents the interests of socially responsible entities in the Czech Republic. Its unique vision involves the social responsibility topic, not only in private companies (CSR) but also in all segments of society, including public administrations, NGOs, social enterprises, 
schools and individuals. Since 2009, A-CSR has run a popular portal about CSR, sustainability and responsible business in the Czech Republic, and it broadcasts information about interesting projects, events or publications in this area. A-CSR is a professional consultant for issues related to social responsibility among the general public, and it participates in a number of successful projects and research.

"TESSEA", an opinion platform supporting social enterprises and the social economy, was created in 2009. The platform was established within the project "Thematic Network for the Development of the Social Economy", which was co-financed by the European Social Fund and government budget. The platform brings together individuals, enterprises, non-profit organisations, universities and other institutions linked by a common interest-namely to promote the social economy and social entrepreneurship and to raise awareness about these among the unprofessional and professional public.

"P3-People, Planet, Profit, o.p.s." is a public-benefit organisation that brings about and promotes new and innovative approaches to business, with a positive impact on society. P3 coordinates TESSEA; it also supports social and socially beneficial business, provides consulting and organises seminars and workshops. Social entrepreneurship is at the centre of P3's attention.

\section{Conclusion}

This chapter summarises the history and current status of social enterprise in the Czech Republic. The long tradition of solidarity, mutualhelp organisations, foundations and cooperatives in the country was interrupted by the period of socialism. The "Velvet Revolution" and the development of the civil sector after 1989 constituted the basis for the emergence of current social enterprises, but the real beginnings of the SE phenomenon in the Czech Republic are mainly connected with the implementation of projects supported by European Structural Funds.

The concept of social enterprise is mainly connected in the Czech Republic with the employment of disabled people. The legislative background supports these social enterprises by providing subsidies for the creation of jobs according to the code of employment. However, thanks to the call issued by the European Social Fund, the concept of social enterprises has become broader and now includes the employment of people belonging to other groups that are considered as socially disadvantaged.

In spite of the lack of a legal form dedicated to social enterprise, we were able to identify four major SE models, which correspond to a large extent to the "international typology of SE models" put forward by Defourny and Nyssens (2017). Though our fourth model (WISE) cannot be considered as corresponding, to Defourny and Nyssens" "public-sector SE model", we stress the fact that work-integration social enterprises, which 
constitute the largest group of social enterprise in the Czech Republic, are strongly acknowledged and supported by the state.

\section{Notes}

1. For more information, see Dohnalová et al. (2011).

2. For more information, see Dohnalová et al. (2011).

3. Czech legislation is generally influenced by international and European legislation/institutions (e.g. the United Nations, the International Labour Organisation [ILO], the Organisation for Economic Cooperation and Development [OECD], the International Social Security Association, the Council of Europe, and their conventions, declarations, charters, resolutions or recommendations). European documents, the Constitution and the Charter of fundamental rights and freedoms are the basis for the national action plan on social inclusion.

\section{References}

Borzaga, C., Galera, G. \& Nogales, R. (eds) (2008) Social Enterprise: A New Model for Poverty Reduction and Employment Generation, Bratislava: EMES and UNDP Regional Centre for Europe and the CIS.

Defourny, J., Develtere, P. \& Fonteneau, B. (eds) (1999) L'économie sociale au Nord et au Sud, Brussels: De Boeck Université.

Defourny, J. \& Nyssens, M. (2017) "Fundamentals for an international typology of social enterprise models", Voluntas: International Journal of Voluntary and Nonprofit Organizations, Vol. 28, No. 6, pp. 2469-97.

Dohnalová, M. (2010) "Sociální ekonomika”, in Skovajsa, M., Pospíśilová, T., Deverová, L., Muhič, S., Moore, D., Holland, T. P., Couf, P. \& Pajas, P. S. (eds) Občanský sektor. Organizovaná občanská společnost $v$ České republice, Praha: Portál.

Dohnalová, M. (2012) Sociální ekonomika, sociální podnikání. Podnikání pro každého, Praha: Wolters Kluwer ČR.

Dohnalová, M., Průša, L., Deverová, L. \& Šloufová, R. (2011) Sociální ekonomika, Praha: Wolters Kluwer ČR, a. s.

Noya, A. \& Clarence, E. (eds) (2007) The Social Economy. Building Inclusive Economies, Paris: OECD.

Rataj, T. \& Ratajová, J. (1998) “Úvodní studie”, in Laštovka, M., Laštovková, B., Rataj, T., Ratajová, J. \& Třikač, J. (eds) Pražské spolky: Soupis pražských spolkủ na základě úredních evidencí z let 1895-1990, Praha: Skriptorium.

Skovajsa, M. (2010) “Organizovaná občanská společnost: teorie a vývoj”, in Skovajsa, M., Dohnalová, M., Pospíšilová, T., Deverová, L., Muhič, S., Moore, D., Holland, T. P., Couf, P. \& Pajas, P. S. (eds) Občanský sektor. Organizovaná občanská společnost $v$ České republice, Praha: Portál. 